\title{
Gifted and Talented?
}

\author{
David Williams \\ St John's College, Cambridge, UK \\ Email: doctordlwilliams@aol.com
}

Received 23 March 2015; accepted 11 May 2015; published 14 May 2015

Copyright (C) 2015 by author and Scientific Research Publishing Inc.

This work is licensed under the Creative Commons Attribution International License (CC BY). http://creativecommons.org/licenses/by/4.0/

(c) (i) Open Access

\begin{abstract}
While I am sure that the majority of papers in this issue will be detailed research reports, I think it may be worthwhile to offer you my recollections on how, as a child in the 1970s who will now be labelled as gifted and talented, I am helped by what must have been a very forward looking local education authority and school to enjoy and excel in mathematics and music. They show how focussed and well directed efforts by a small number of people can make a profound difference to the educational experience of a child labelled as gifted and talented without necessarily requiring significant changes to the teaching strategies for the rest of the class in which that individual finds himself.
\end{abstract}

\section{Keywords}

\section{Mathematics, Music, Gifted, Provision, Encouragement}

\section{Introduction}

I guess I have never really liked being called gifted and talented, though I suppose getting a place to read veterinary medicine at Cambridge, and now being on the other side of the table as a fellow at St John's College, deciding who gets to study my subject puts me fairly and squarely in that camp! Maybe it's better than being called a swot, which it must be said is what I was, working all hours God sent to ensure I got the grades I needed for vet school. And still am, if I think about it - why else will I be spending my Sunday afternoon writing this little autobiographical sketch?! Let me take you back a few years. In 1972, my mother was in somewhat of a quandary. The secondary education system in Cambridge was turning comprehensive and I was in the first year of that change. Should I go to the Girls' Grammar in the middle of town where all the kids with some brains from our junior school seem to be heading, or to the Secondary Modern just down the road? Clever lady, she reckoned that the teachers in the latter school would be encouraged and inspired by having students keen to immerse themselves in academic study and would in turn enthuse and inspire their charges. She was right. But the local education authority was concerned as well. How were they going to stimulate the brighter children in a 
school which had for its previous whole history existed to provide skills in resistant materials (what we then called woodwork and metalwork of course!) for young people destined for the light industry which then took up the majority of those leaving so-called secondary modern schools at the age of 16 . The teachers certainly played their part. It is only now that I see what a challenge it must be suddenly to be confronted with students keen and willing to learn at the same time as having to cope with those who just did not want to learn, What the education authority did was to organise a number of weekend events for "the bright kids" to stimulate us. I well remember some of these, ironically held in the teacher training college where I went to nursery school and which has now morphed into the Faculty of Education where I am currently undertaking a part time Masters in Education - how the wheel comes full circle! Anyway, we must get back to the subject-my students always amusedly complain that I get diverted onto far too many tangential digressions!

\section{Weekend Activities}

The best of these weekend activities was one that ended up lasting for the whole of my secondary schooling. Four of us met every Saturday morning in the home of Professor Warwick Sawyer a quite amazing mathematical educator, author of such masterpieces as Mathematician's Delight written in 1943 primarily to educate those destined to be engineers in the maths they needed and, for those with a deeper interest in the subject (Warwick, 1943) A Concrete Approach to Abstract Algebra (Warwick, 1959), both still available through the Brazilian rainforest beloved of bibliophiles. Professor Sawyer had recently retired from the University of Toronto although his career had taken him around the world with posts in Ghana, New Zealand and the States, finishing up in Canada. Sawyer always wanted to apply his maths to something practical, as those two books so well illustrate. On that first Saturday morning, while his wonderful wife Betty supplied us with seemingly endless drinks and biscuits, he asked us what we were interested in. I said that astronomy was a passion of mine and that I was trying to make a six inch Newtonian reflecting telescope. Why did I have to grind the mirror to a parabolic shape rather than a sphere which would have been so much easier? That, as those of you familiar with maths and physics will be aware, takes us into the intricacies of Cartesian geometry, but Sawyer explained it so deftly and entertainingly that we soon understood even though we would not encounter this for years in our school maths courses. And here was the key-first something that interested us, indeed topics that we came up with ourselves, and secondly not just a topic that involved reading the next few pages of the maths book we were using at school. Just getting the $\mathrm{G}$ and $\mathrm{T}$ (I had never thought of myself as an enjoyable alcoholic beverage before now!) to read on to the next chapter perpetuates the problem of them being a step or two ahead of the rest of the class. We were particularly lucky in having Professor Sawyer on our doorstep, a true world-class educator. But I remain convinced that every school can find a parent, grandparent or a local tertiary educator who, with some encouragement, could provide a similar opportunity for similar students. And broadening interest is by no means only confined to subjects already being studied at school of course.

\section{A Musical Interlude}

In my mid teens I was given the opportunity to join a wonderful week's course in the Early Music Centre in London, a forerunner of the National Centre for Early Music in York which has much of its focus on education. As a single parent family we did not have enough money for a piano and having ear problems that precluded taking up a wind instrument and a mother who didn't like the idea of listening to a screeching violin, I studied the classical guitar. The early music course taught each young musician to try the Renaissance equivalent of the instrument they were currently playing. While the violinists played viols and the wind instrumentalists experimented with shawms and sackbutts I, as the only guitarist on the course, had the privilege of tuition by world experts such as Tony Rooley, Tim Finucane and Chris Wilson and the opportunity to say I have accompanied Emma Kirkby singing Dowland songs. My lute playing continues to this day, though by no means at their standard!

\section{Stimulation}

Looking back the interesting thing was that these specific opportunities did not impact on work at school. The maths we did with Professor Sawyer was completely different from the SMP (Schools Mathematics Project) books we were working through at school and the music was at a completely different level, and depth, from 
anything offered at my school, even though it had (and still has) some great music teachers. Karen Rogers has argued that gifted and talented students need "daily challenge in their specific areas of talent" (Rogers, 2007: p. 383), but I am not sure that this is the case. The opportunities provided for me where by no means this frequent, but still stimulated through the rest of the week, just knowing that there was a morning of being stretched every Saturday kept me going through the week. Bloom's (1985) longitudinal study on development of eminence in different fields showed that a continual progression of increasingly difficult challenges was important as Sawyer provided without us even realising it! Rogers' second lesson on educating the gifted and talented talks of "opportunities... provided on a regular basis" (Rogers, 2007: p. 385) which certainly fitted with Sawyer's Saturday mornings but not with the Early Music Centre's opportunity which was a one off by extended and deep for sure. Rogers" third lesson asks for "subject-based and grade-based acceleration as educational needs require" (Rogers, 2007: p. 86) following Colangelo, Asouline, \& Gross's (2005) book “A Nation Deceived". But the whole point of the stimulating initiatives from which I benefitted were not to accelerate me along the path I would normally be taking, thus accentuating problems further down the line but rather providing opportunities in parallel with what was being provided at school. Rogers' fourth lesson is to "provide opportunities for gifted learners to socialise and learn with like-minded peers" (Rogers, 2007: p. 390) and this was exactly what those Saturday mornings provided. Not just chances for one on one teaching from the expert but the small group teaching that we pride ourselves in giving in college supervisions in the University of Cambridge. In our Saturday morning group just as in supervision in college the students stimulated one another quite as much as being encouraged and pushed forward by the college educator or Professor Sawyer himself all those years ago. And we stimulated him, too. I visited him in Scarborough, Toronto at the age of 95, a couple of years before he died and his eyes sparkled just as they had when we first studied under him, when he remembered the fun we all had on those Saturday mornings 25 years earlier.

I said at the beginning that I don't like the term gifted and talented, though actually looking at those words etymologically they are quite as much about what the student does with what he or she is given, as the provision itself. The key thing is that, as in Jesus' parable, the talents are to be used to best advantage rather than buried in the ground. And while that is obviously the responsibility of the child thus "endowed", the role of educators and educational authorities in providing the opportunities and encouragement to take them up cannot be underestimated.

\section{Conclusion}

This short autobiographical offering shows how valuable the provision of well focussed extracurricular educational activities can be for gifted and talented students. The opportunities described here are unique, but it is hoped that they show a great influence such activities can have on the development of young people by encouraging and developing their passion for learning, which can have lifelong benefits.

\section{References}

Bloom, B. (1985). Developing Talent in Young People. New York: Ballantine.

Colangelo, N., Assouline, S. G., \& Gross, M. U. M. (2005). A Nation Deceived: How Schools Hold Back America's Brightest Students. Iowa City, Berlin: Blank Center for Talent Development.

Rogers, K. B. (2007). Lessons Learned about Educating the Gifted and Talented, a Synthesis of the Research on Educational Practice. Gifted Child Quarterly, 5, 382-396. http://dx.doi.org/10.1177/0016986207306324

Warwick, W. W. (1943). Mathematician's Delight. London: Penguin.

Warwick, W. W. (1959). A Concrete Approach to Abstract Algebra. London: Freeman. 